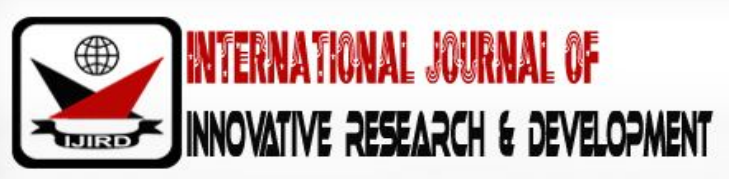

ISSN 2278 - 0211 (Online)

\section{Peace Education as a Process for National Development in Nigeria}

\author{
Jibrin Ubale Yahaya \\ Part Time Lecturer, National Open University, Nigeria
}

\begin{abstract}
:
Peace education is a right tool that can be used in the process of Nation building and development. For any society to attained a peaceful atmosphere, that society must consider the dimensions of peace from social conditions that foster a better situation for individual, groups and the society in general in terms of political, economic and socio-cultural angle. Nigeria as country with over 180 million populations and also over 250 ethnic tribes has in various times suffers the cases of conflict between different groups as a result of differences of religion, tribal and regional identities for a very longtime since the Nigerian Independence in 1960, the paper observe for Nigerian to meet the level of development, the country, must have a good and functional leadership whose consider Nigeria first before his/her tribe or ethnicity and the country to have an education policy or enlightenment programs that teaches all the citizens the importance of tolerance, collaborative effort, and understanding among various ethnic groups as well the notifying them the dangers of violence, conflict and war in the society. The major aim of this paper is to use peace education as a tool that will promote effective social relations between individuals and various groups in Nigeria through demonstration of social understanding, critical thinking, problem solving ability to use cooperative means of resolving conflicts than the uses of hatred stereotypes and bad emotion that only led to violence.
\end{abstract}

Keywords: Peace education, nation building, conflict ethnic tribe

\section{Introduction}

Conflict is a substance and normal part social living. Conflicts can be small or large, obvious or hidden and brief or long lasting. Conflict happens at different level of the society depending on the issue at stake that may trigger the conflict to emerge. As argued by Deutsch (1993) although conflict are inevitable in social relation, peoples can approach conflict constructively as a well as destructively. As also cited by Optow (2000) view that "even when co operative Processes fail, opposition, protest, and non violent as well as non cooperation.

However, its cited above from the view of Deutsch conflict can be negative or positive or to refer it in the aspect that is when a groups or individual in the society have a kind of misunderstanding or grievances with other or even the state but use the right source in demonstrating his anger and the party understand the gap by seen the danger of conflict escalation and adopted peaceful measure of addressing the problem this mean the conflict is a good one because it is constructive and developmental in nature that does not call for destruction or damage of social relationship.

Secondly, when a party to conflict as an individual or group that fight for destructive nature of killings and damaging of properties result of strife between individuals or group in the society, that conflict become destructive and many led to damages of lives and properties as well as damaging of existing social relation between the parties. Abdullahi, A. (2002) has argued "no part of Nigeria can consider itself safe when other parts are burning the threat of anarchy in any part of our country is the threat of anarchy in the entire nation. Our nation can develop meaningfully and nature of its democracy only in a peaceful atmosphere in which respect for human lives and property is a fundamental article of our national faith. We believe are all committed to the sustenance of democracy in our country. We believe we are all committed to moving Nigeria for word in peace and not in pieces.

Conflict according to the Chinese, is an opportunity to change this show us the conflict is neither negative nor positive, what makes conflict a bad attitudes is when we perceives a conflict as war, disagreement fight, chaos, aggression, destructions, crises, cheating, misunderstanding, suppression and sets a conflict as a reaction through revenge, fight back, defense, counter attacks which brings about a negative result. While in the other side's a person or group perceives conflict as a necessary dimension of peace, progress, change, development, understanding, resolution, friendship, interaction, love and many other things which can brings about positive result. 
Ezema, (2012),"Peace is essential in attending a lasting development and, it is vital to the achievement of the millennium development goal". Peace is one of the essential elements that will be found in the process of attaining National development where the society can enjoy the full benefit of social, economic and political aspect that every individual can contribute towards a nation building, sustenance and development.

\section{Definition of Concept}

\subsection{Peace Education}

Peace education is a component of education aspect that teaches the members of the society the values of understanding respecting the views of others and tolerance attitude that demonstrate peace and unity.

Haris \& Synott (2002) has view peace education "as the process of acquiring values, the knowledge and developing the attitudes, skills and behavior to live in harmony with one self, with other and with the natural environment". Peace education is an aspect of education that in calculate the values to individuals and groups the importance of life skills and knowledge in the spirit of equality, respect, empathy, understanding and mutual appreciation among individuals, groups and nation. The knowledge of peace education enable individuals or groups to attain the level of human development, fighting poverty, unemployment, prejudice, violence conflict, discrimination and violence against women and children.

Peace education is concerned with the development and discovery of knowledge about the causes of war and the conditions of peace component in the society. Ruth fire (2002) views peace education" as the continues education that youngster and adults have been receiving since the beginning of mankind. Peace education is a type of education that an individual Hearn from the family level up to the societal level on the basis of non violence attitude avoidance of war.

Vrieas (1990) argues peace education as a difficult task even in a relatively more peaceful community and concludes that although studies of children's lack of sustainable peace led to poor socio-cultural economic and political development of Nigeria as result of ethnic religious, political violence has distorted the, nation economic structure and damages the social relationship that exists between the various ethnic groups in Nigeria.

Nigeria was divided by some political sentiment by various leaders from different zones in Nigeria in order to achieve their selfish interest or goals. However, peace education program is a package of knowledge that teaches us the importance of values, custom and its application of the culture to contribute to better understanding of each by preventing or managing the bad culture of prejudices, negative stereotypes and crisis or misunderstanding among various ethnic groups in Nigeria.

Danesh (2006) has argued that peace education refers to these aspects of formal and non-formal education in school and out of school aimed at elimination group prejudices, stereotypes and hatred which make people prefer peace to war, non violence to violence, cooperation to exclusion, acceptance to discrimination and construction to destruction"

Peace education as exited tool for societal transformation which encompasses both the school program and out of school activities aims at engaging the society to rob mind and thinking of cooperation and understanding between individuals or group and avoid hatred, misunderstanding and violence which is one of the ending factors to conflict and war in the society. Conception of war and peace are very important for the realization of a balance peace education strategy "While the United Nations (1998) states "The culture of peace is based on the principles established in the character of the united nations and on respect for human rights, democracy and tolerance, the promotion of development, education for peace, the free flow of information and the wider participation of women as an integral approach to preventing violence and conflict and efforts aimed at the creation of conditions for peace, the free flow information preventing violence and conflicts, and effort aimed at the creation of condition for peace and its consolidation.

Peace education, as cited by the United Nations, can be sees as avenue of observing the fundamental human rights, consolidation and empowering of democratic process in the country, peoples participation in governance as well as prevention of acts or actions that may led to violence and conflict in the society.

Pope Francis (2013) has also argued that peace education "is necessary in Nigerian education system and curriculum because of political instability, unplanned migration due to violence social injustice and consequent poor economy and standard of living.

Peace education as a component of educational curriculum need to be a medium that can promote National Unity, economic development and tranquility that can more the nation forward.

According to Solomon (2002) views peace education "as region of relative tranquility that stress education for cooperation and harmony, there by promoting the idea of general" culture of peace "where as regions of conflict emphasis, education for violence prevention." Peace education in Nigeria will help us to avoid violence and criminal activities instigated by insecurity and other violence emerges as a result of many other political forces.

\subsection{Development}

The concept of development has been discussed by various scholars, development institutions and other policy makers with a different dimension and understanding of the subject matter based on some certain parameter or yard stick about the level of nation economic growth, standard of living of the citizens and the level of peoples participation in governance process. 
Todaro (1981) has a position of the concept of development that in essence must represent the entire gamut of change by which an entire social system, tuned to the diverse needs and desires of individuals and social groups within that system moves away from a condition of life widely perceived as unsatisfactory towards a situation or condition of life regarded as materially and spiritually better (P.70) while the thermal (1980) has cited that development is understood principally in terms of economic progress, the presence of copious infrastructural facilities, super highways impressive building.

The two definitions of scholars about development the researcher sees development as a multi dimension and complex structural factors that must be merge together in order to give a one single structure which need to bring substance variables of both socio-cultural, political and economic aspect to build a strong structure that can be called as a development at whatever level.

Okowa (2005) has also argued that development include growth, income distribution, poverty all aviation and provision of basic needs of food, shelter, health and education masses aspect of economic growth indices through income distribution circulation between the citizen, which reduce the level of poverty among citizens as well as the nation has a system that provided for the basic human needs of the country citizens every in terms of good road network, health care delivery, qualitative education, water supply and other essential basis human needs of the citizens.

\subsection{Peace}

Peace is one of the Key factors that will drive the society to the level of a certain desired development status. No society can enjoyed the level of sustainable development without the existence of peace. Haavelrud (1996) has .observe peace "as a dynamic social process in which justice, equity, and respect for basic human rights are minimized and violence, both physical and structural is minimized." This means when in a society if there is display of justice, equity and respect for the observance of basic fundamental human right that means is equally inviting for peaceful living, when there is injustice and breaches for the fundamental human rights this indicate the absence of peace.

Reardon \& Cabezudu (2002) cited peace requires social conditions that foster individual and societal well-being. According UN 1992), document. "An agenda for peace in that document identify peace" as an action to identify and support structures which will tend to strengthen and solidify peace in order to avoid a relapse in to conflict."

Based on the UN (1992) document peace an action that target towards various efforts that will ensure the sustains of peace in the society through strengthening any actions that will promote peace and avoid action that may led to the emergence of violence or conflict.

Peace is concern with the elimination of violence where is an act or process which in peace people from realizing their potential (Baunet 2001 in Gazting 1969) while Harris (1999) has argued and maintain that peace keeping in a school can be understood as peace through control, this approach blame youth for the dysfunctional behavior they have adopted from the environment that surround them.

We can under standard that violence as a behavior exhibit youth is a byproduct of what was been found in the society they are living in a simple form conflict can be emerge as a result of social invention between individuals, groups in the society which is in evitable but the issues to raised here is for the members of the larger society to adopts cooperatives, understanding and tolerance in the process of interaction and avoid violence and hatred among themselves.

\subsection{Causes of Ethnic Conflict In Nigeria}

Nigeria is a country that was been amalgamated between the Northern Region and Southern Region since 1914. Despite the difference in tribal identity and religious factor. As argued by some scholars a state with divisions are disposed to be delicate and unstable because almost by definition, they have a very little in common with regard to convergence and harmony which are necessary to reduce the centrifugal farcies trip than a part (Osaghare and Soheru 2005;4).

So here, paper will observe what promote ethnic conflict in Nigeria are as follows:.

\subsubsection{Tribalism}

Tribalism is a nation that signifies the differences in claiming tribal affiliation identity, where the loyalty to the ethnic group overrides the display of actual nationalism and unity of the country.

Here, we can understand that tribalism is a force influence that generates conflict in various communities in Nigeria. Tribalism is also a tool that divides the peoples of different tribes.

\subsubsection{Corruption and Bad Leadership}

Corruption as a concept is a process using official advantages or influences in order to gain a financial, social or political benefit.A high level of corruption and the looting of state resources is another serious and pandemic (Dike, 2005). Ogbeidi (2012) as argued that the problem that makes all forms of conflict and trouble worse in Nigeria, the country is rich endowed with natural resources and high quality human capital.

Corruption in Nigeria brings about underdevelopment that led to poverty, this make some citizens that are poor are feeling hatred and anger to the wealthy individuals in the society.Nwankwo (2015) has cited poverty and injustice caused by corruption tolerance, social solidity or coexistence, while reawakening social hatred, radicalism and violence. 


\subsubsection{Religious Factor}

Nigeria has three major ethnic groups of Hausa Fulani, Yoruba and Igbo. The Hausa Fulani are predominant not Muslim community, Igbo and other minorities group living in the south are Christians. While Yoruba are half Muslim and half Christians who are living in the south - West

Lewis (2007:6) has cited the historical provenance of Islam during the formation of Northern states in the early 19th century to the continued provenance of Emir and religious authorities in framing identities in the Northern Nigeria.

Conflict between Herdsmen and Fulani killings by group suspected to be Fulani leadsmen in various part of the country without section from government, had give a green light for these groups to launched attack to farmers in states like Benue, Nassarawa, Taraba, Kaduna and Zamfara. There is long lasting of conflict between Fulani and farmers as result of misunderstanding between the groups.

\subsubsection{Resource Control Conflict}

Nigeria is one the major oil producing state in the world, the emergence of the crude oil in the early 1960 has become a new dimension of conflict in the Niger Delta zone. hazards.

Akpan (2006) has cited the exploration of petroleum product brought in a train of severe social and ecological

Conflicts in Niger Delta region has become a national issue immediately after the returns of democratic rule in 1999 but the Niger Delta youth become seriously violent in destructive manner from 2003-2007, very unfortunately during from late president Umaru Yar'Adua has granted an amnesty program to the Niger Delta Youth to be trained both at home and abroad on various vocational training to become self reliant during that time the youth reduces the attacks because of financial benefit they gaining from the government.

So here, the paper has argues that for a one certain one partly of the country to be claiming the ownership of national resources despite the higher benefit of the national resources but they are not satisfied with the sharing formula that led to the agitation for resources control as a result of poor government operations in the country.

\subsubsection{Religious in Tolerance}

Nigeria as a country has the power domination of two major religions of Islam and Christianity. The in story of religious in tolerance has caused the riot that took place in Kano on May 1, 1953 which has led to series of violent attacks against non-Muslim in the country.

The conflict between Muslim and Christianity was the control of dominance of one another as stated before the majority populations of Northwest are Hausa/ Fulani who are Muslim community, while North East has over $65 \%$ of Muslim Community, (30\%) Christians and 5\% not Muslim not Christians, while those in South-West are 50\% both Muslim and Christian, South - South over 90\% Christians, North central domination of 50-50\% control of both the two religious (Palen, 2007: Olajo 2014:4).

Religions as a contention of individuals of groups believe on what to worship but most of the religion are frying to have over domination and power control over groups.

\subsubsection{Peaceful Resolution of Conflict}

The essence of peaceful resolution is to prevent or control the escalation of conflicts from confrontation that can lead to war.

\subsubsection{Peace Making Process}

This a systematic peace process where diplomatic initiative that will bring to an end to any violent attitude that the conflicting parties may shift for peaceful and understandable position.

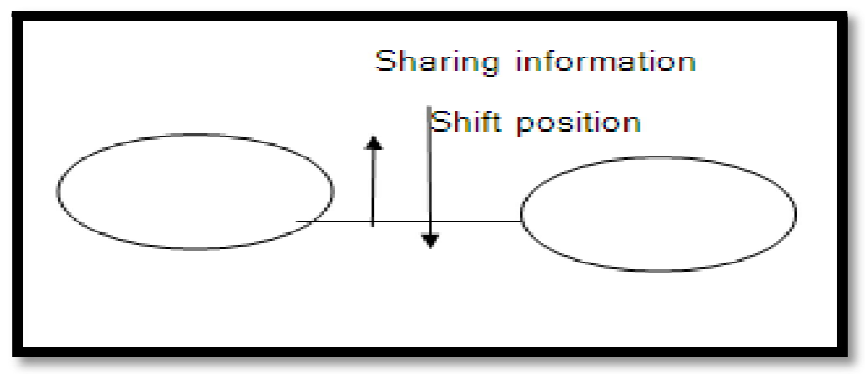

Figure 1

However, in any conflict situation the important aspect of peace making is for the both parties to agree to change a position from bad thinking, hatred, violence to good position of understanding and living each others 


\section{Medication}

Conflict cannot be resolve in some certain level unless with intervention of third party, who will be a mediator. Keither (1983) cited that "mediators is not just a note takers rather he or she is active in the process, constantly persuading the parties toward agreement of course, sometimes one party is facilitated or listen to then the other and mediator has to be a good listener at all times". While in other side mediators is really working for the relationship trying to bring the parties in to accord. (Prnitt and Johnson 1970)

Mediator is a third party agent that can help the conflicting parties to reach a level of understanding and agreement for settlement.

Negotiation parties.

According to Rubin B, (1975) state technically that negotiation is a process by a joint decision is made by two or more

Negotiation process is a activity which serve to observe the exchange between the conflicting parties, where parties agree to negotiating by working with other party to attain a certain peaceful ground.

Bargaining is very important in resolving conflict when parties bring burning issue on the table and efforts where honestly fish out to address the problem.

\begin{tabular}{|c|c|}
\hline Identification of Problem & Third Party and Conflicting Parties Involve \\
\hline Discussion of Problem & Both Parties \\
\hline Bargaining and reaching agreement & Both Parties \\
\hline Finding Solution to the Problem & Both Parties \\
\hline Restorations of Peaceful Condition & Both Parties \\
\hline Peace Building Structure & Relevant Stake holders. \\
\hline
\end{tabular}

Table 1: Societal Peace Restoration Table Chart

Source: UN Peace Talk 2013

Many scholars of social science and humanities has debated on the two concept of mediation and negotiation. However, the mediation has requires the intervention of the third party agent helping the conflict to reach an agreement while in the negotiation the parties are voluntary agree to resolve their differences without even the intervention of the third party.

\subsection{Conflict Handling Styles}

There various ways or means where conflict between groups or individuals can be handled as a result of conflicting views, ideas, .values and believes. He nature of the attitude and the behavior of the parties involves determines the failure or success of conflict resolution process.

\subsubsection{Assertiveness}

Assertiveness this is the means or process where on individual or group try to satisfied his needs and concern to ensure he desired goal will be attained, this may led to escalation of conflict.

\subsubsection{Cooperativeness}

In this aspect the person or individual or even the group want to satisfy his needs and concern as well as the other parties needs, through the following five means of handling conflict styles dominating completing, accommodation, avoiding, collaboration and compromising.

\subsection{Conflict Tracking and Mapping}

According Wehr (1979:18) sees "conflict mapping as a first place or step in intervening to manage a particular conflict. Conflict mapping is a picture of graphical representation of the conflict in which the conflicting parties are placed in relation to the situation on the ground.

The reason behind conflict mapping is to evaluate and examine conflict clearly from root point of view and open strategies on how to address the lying problem.

While conflict tracking is the process which involves monitoring, observing and recording the trend of change and continuity in conflict in conflict process. There are some certain thing to consider which express the re-definition of goals and finding alternative means of resolving differences.

\section{Recommendation}

The paper has the opinion that peace education as a component of learning process can be used to address the lingering emerging crises and conflict in Nigeria through the following means: - 
- Leadership structure in Nigeria should be a call service to humanity by displaying responsiveness, accountability and transparency in the process of managing government affairs, where leaders should be dedicated to the nation first than their tribal or ethnic identities.

- Creating a series of program those in-school activities where students are teachers at various levels of educational system. The values of peaceful living and dangers associated with violence and conflict.

- Engaging traditional institution both traditional headers and religions headers in the campaign towards educating large members of the society the importance of tolerance and avoidance violence

- Media should map out various educational activities on peace in their stations to reach mass number of the population.

- $\quad$ Adapting peaceful means of addressing confect by fading the roof the issue.

- Judiciary should be functional by displaying justice to whoever instigate confect in the society at whatever level he/ she is in the society.

\section{Conclusion}

Many nations have reached the level of development as a result of peaceful environment because it attracts foreign infesters that supplement the national earring. Peace education can be for the overall development of the society.

\section{Reference}

i. Abdullahi A. 27 January 2002, Seminal Of Ethnic Conflate Nigeria at Nassarawa State.

ii. Boufros Ghali B. (1992). An agenda for peaces new your united nations.

iii. Denesh H.B (2008) Creating A Culture Of Healing In Schools And Communities. An Integrative Approach to Prevention and Amelioration Violence Induced Conditions. Journal of Community Psychology.

iv. Ezema, P.N 2 Ezema, (2012) Teacher Education As A Sustainable Strategy For Building Of Peace And Implementing The Millennium Development Goals Is Rural Nigeria. Global Voice Of Education (I).

v. Galtuh J. (1990) Cultural Violence, in Journal of Peace Research 27:3

vi. Harns, I. \& Synoft J. (2002) Peace Education For A New Country, En:Wikipdia Org(Wiki)Peace Education Retrieved, May 2013.

vii. Nwankwo, B. (2015) rhetoric and realities of managing ethno-religions conflicts; the Nigerian experiences. American Journal of educational research (3) pp. 292 - 300.

viii. Okwa, W.J. (2005 "Oil Babylonian Atter Conomics and Of Port Harmony.

ix. Ogabeidi M. (2012) Political leadership and corruption in Nigeria since 1960. A socio-economic analysis. Journal of Nigeria studies jononal of Nigeria studies, 1 (2) pp. 1-25.

x. Paden, N. (2007) contemporary religious dynamics in Nigeria. The religious conflict in Nigeria symposium session 2 8 may 2017, New York, foreign relations.

xi. Pope Francis (2013). Homily At Thangaration Of Pattering Ministry Mass, Owerri Leader Sunday, March 17P4.

xii. Theoma, E.O (1983) "Education And National Development” In Journal Of Education In Developing Areas (2) 120-127.

xiii. Solomon, G. (2002) The Nature Of Peace Education Not All Programmes Are Created Equal. "In Salomon G. And Nevo B. (Eds) Peace Education: The Concept Principles and Practices In The World. Malwah. N.J. Lawrence Eribaum.

xiv. Todaro, M.P (1981) Economic Development in the Third World (8th Ed), London", Longman Publisher.

xv. Lewis P. (2007) identity institutions and democracy in Nigeria. Afro barometer working paper. No. 68 